\title{
Tiedontuotanto poliittisen päätöksenteon tukena - koronavirusepidemiasta tuotettu tieto
}

\section{ALEKSI YRTTIAHO JA PEKKA RISSANEN}

Tietoon pohjautuvan johtamisen ajattelutavan mukaan johtamisongelmissa vastataan kysymyksiin, miten tiedosta luodaan arvoa, miten toimintaa johdetaan tiedon avulla ja millä välineillä johtamista tuetaan (1). Johtamisessa käytettävän tiedon pitää olla käytettävää, oikea-aikaista ja valottaa käsillä olevaa ongelmaa. Sama pätee, oli kyse valtakunnallisesta, alueellisesta tai yksilöllisestä päätöksen teosta. Tämän lisäksi tietoa käyttävällä tulee olla riittävä toimivalta toimia tiedon ja siitä tehdyn tulkinnan mukaisesti.

Toimivaltakysymykset ovat nousseet keskeiseksi myös tietoon pohjautuvien päätösten toimeenpanossa, kun koronaepidemian leviämistä on hidastettu. Tartuntatautien torjunta on kuntien ja sairaanhoitopiirien vastuulla ja Terveyden ja hyvinvoinnin laitos (THL) on tälle työlle tukiroolissa. Päätökset rajoitustoimista ja niiden valvonta vaatii monissa tilanteissa useiden eri sektorien välistä yhteistyötä. Terveydenhuollon toimijoiden toimivalta yksilöön nähden edellyttää aina jokaisen henkilön lääketieteellistä arviota.

Joissain tilanteissa tietoa voidaan käyttää suoran johtamisen sijaan ohjaamisen työkaluna. Esimerkiksi THL on kerännyt tietoa kuntien ja kuntayhtymien tiloista, tarvikkeista ja kapasiteetista koronavirustaudin testauksen, jäljityksen ja hoidon tarpeisiin. Sosiaali- ja terveysministeriö ja THL pystyvät tämän tiedon perusteella asettamaan ja seuraamaan tavoitteita sekä tukemaan ohjausta eri instrumentein, muun muassa rahoituksen avulla. Toimivalta tavoitteiden saavuttamiseksi on kuitenkin kunnilla ja kuntayhtymillä sekä yksityisillä yrityksillä.

Ajoittain näennäisesti arvokasta tietoa ei voida hyödyntää lainkaan päätöksissä. Keväällä ra- joitettiin suomalaisten vapaata liikkuvuutta ja suositeltiin etätyöskentelyä. Matkapuhelinverkkojen ja ihmisten jakamien GPS-sijaintitietojen perusteella pystyi tarkastelemaan, miten käyttäytyminen muuttui rajoitusten tullessa voimaan. Tietoa jaettiin muun muassa mediassa. Vaikka tietoa periaatteessa oli käytettävissä, se lähinnä vastasi uteliaisuuteen ja parhaimmillaan auttoi tukemaan toivottua käyttäytymistä yhteisötasolla sekä ennakoimaan mahdollisia tartuntakeskittymiä. Sosiaali- ja terveydenhuollossa ei kuitenkaan ole toimivaltaa tehdä päätöksiä, joissa tämän kaltaista tietoa olisi mahdollista hyödyntää.

Kaikkeen kerättävään tietoon tulee olla selkeä käyttötarkoitus. Tämä korostuu henkilö- ja terveystietojen kohdalla. Kerätyn ja käytetyn tiedon määrä tulisi minimoida eikä tietoa saa käyttää muihin kuin sille ennalta määriteltyihin käyttötarkoituksiin. Käyttötarkoitusperuste rajaa sen tiedon määrä, jota kerrytetään vakiintuneeseen tietopohjaan.

Koronaepidemian edetessä on ollut tärkeää myös seurata ja tunnistaa, että kerättyjä tietoja todella käytetään. Jokainen tiedonjyvä sisältää mahdollisuuksien lisäksi kuitenkin myös taakan, joka syntyy tiedon tuottamisesta, keräämisestä, käsittelystä ja turvaamisesta. Sen vuoksi päätöksen tueksi tulisi olla käytettävissä pienin määrä tietoa, jolla voidaan tehdä oikea päätös ja seurata sen vaikutuksia.

Suomi on yksi terveydenhuollon sähköisen tiedonhallinnan sekä tilasto- ja rekisteritoiminnan johtavia maita (2). Meillä on pitkä perinne yksilötason tietojen kokoamisesta kansallisiin tietovarantoihin. Eri tietovarantoja on mahdollista yhdistää henkilötunnuksen avulla. Terveydenhuol- 
lon Kanta-palvelut ovat vakiintuneet osaksi toimintakenttää (3), kansalliset rekisterit kattavat suuren osan sosiaali- ja terveyspalveluista. Lisäksi sosiaali- ja terveystietojen toissijaisen käytön lainsäädäntö uudistui vasta, mikä auttaa tietopohjan laajentamisessa.

Tammikuussa 2020 Suomessa todettiin ensimmäinen covid-19 -tartunta ja tauti alkoi levitä maaliskuussa. Uusi ja poikkeava tilanne on ollut koetinkivi kansalliselle tietotuotannolle, tiedolla johtamiselle ja tiedolla ohjaamiselle.

THL ylläpitää kansallista tilannekuvaa epidemiatilanteesta ja sen vaikutuksista yhteiskuntaan, erityisesti sosiaali- ja terveydenhuollon tarpeeseen ja saatavuuteen. Tilannekuva koostuu havainnoista (mitä on tapahtunut), niiden tulkinnasta (mitä tämä tarkoittaa ja miten tilanne kehittyy) ja näistä johdetuista toimenpiteistä (mitä pitäisi tehdä, jotta tilanne kehittyy suotuisasti) (4). Yleiseen tilannekuvan ylläpitoon kuuluu päättäjien informointi.

Sosiaali- ja terveydenhuollon kansallisen tilannekuvan havaintojen keskeinen lähde ovat valtakunnalliset henkilörekisterit sekä niitä täydentävät tiedonkeruut. Havaintojen tulkinta ja toimenpiteet puolestaan nojautuvat tieteellisen tiedon soveltamiseen vallalla olevaan tilanteeseen.

Koronavirusepidemia nosti tilannekuvan kannalta esiin useita haasteita. Epidemian aiheuttanut koronavirus SARS-CoV-2 oli uusi virus, jonka ominaisuuksia ja vaikutuksia ei tarkkaan tunnettu. Valtakunnallisen päätöksenteon piiriin nousi uusia tietotarpeita esimerkiksi käytössä olevista tiloista, laitteista ja varusteista, joita ei ennen ollut koettu merkitykselliseksi yhteiskunnallisen päätöksen teon kannalta. Havainnoinnin ja siitä johdettujen päätösten tuli myös tapahtua sekä alueellisesti että valtakunnallisesti aikaisempaa nopeammin.

\section{TILANNEKUVAN UUSI OIKEA-AIKAISUUS}

Päätöstilanteessa tulee olla käytössä olennainen ja ajantasainen tieto. Jos tieto on käytettävissä vasta päätöksen jälkeen, sen merkitys vähenee. Lisäksi päätöksenteon kannalta liian myöhäinen tieto voi merkitä, että tietoa on tuotettu turhaan. Tieto tulisikin tuottaa oikea-aikaisesti; ei liian myöhään, ei liian aikaisin.

Sosiaali- ja terveydenhuollon kansallista tietopohjaa käytetään valtakunnallisen ja alueellisen terveyden ja hyvinvoinnin strategisen tason suun- nitteluun, päätöksentekoon ja ohjaukseen, toiminnan ja palvelujen arviointiin sekä tilastointiin ja tutkimukseen $(5,6)$. Näissä käyttötarkoituksissa tieto on ollut riittävän oikea-aikaista, mikäli edellisen tilastovuoden aineistot ovat olleet käytettävissä osana päätösten valmistelua. Tämä tietotuotannon tahti on kuitenkin todettu liian hitaaksi, jotta tietoa voitaisiin hyödyntää laajemmin alueellisessa päätöksenteossa, erityisesti tuotannon ohjauksessa, tai epidemioiden tunnistamisessa.

Viimeisen vuosikymmenen aikana THL onkin lyhentänyt tietotuotannon viiveitä ja parantanut tiedon oikea-aikaisuutta eri käyttötarkoituksiin. Hyvästä kehityssuunnasta huolimatta tietotuotanto ei ole ollut riittävän nopeaa koronaepidemian kannalta.

Epidemian aikana jokainen tietotuotannon viive on liikaa. Viiveet syntyvät prosessin eri vaiheissa. Osa viiveistä aiheutuu tarkasteltavaa taudin ominaisuuksista ja osa terveydenhuollon prosesseista. Osa puolestaan on kiinni tietotuotannon tehokkuudesta ja vaihtelee lähteittäin. Viiveiden vuoksi havainnot koronavirusepidemian tilannekuvassa kertovat noin viikkoa aikaisemmin vallinneesta tilanteesta. Havainnot kehittyvät luotettavimmiksi, kun uutta tietoa ja tapauskohtaisia korjauksia kertyy.

Myös itse koronavirustautiin liittyy viive: koronavirustaudin itämisajaksi on arvioitu keskimäärin 4-5 vuorokautta. Terveydenhuollon prosessista aiheutuu lisäviivettä, sillä oireiden alusta näytteenottoon ja testitulokseen saamiseen voi kulua useita päiviä. Tämän jälkeen lisää viivettä syntyy tiedonkeruusta ja raportoinnista. Terveydenhuollon palvelunantajat ilmoittavat epäilyt ja laboratoriovarmistetut tautitapaukset tartuntatautilain (1227/2016) mukaisesti valtakunnalliseen rekisteriin hoitoprosessin eri vaiheissa. Valtakunnalliset raportit päivittyvät uusilla ilmoituksilla viimeistään seuraavana päivänä.

Tilannekuvan havainnot koostuvat useista eri tietolähteistä, joilla on myös omat viiveensä. Potilasasiakaskirjamerkintöjen tulee olla hyväksyttynä ja arkistoituna viimeistään 5 vuorokautta käynnin tai hoitojakson jälkeen, minkä jälkeen tiedot päivittyvät rekistereihin ja Kanta-palveluihin. Tieto kuolemasta päivittyy väestötietojärjestelmään tyypillisesti kahden viikon kuluessa. Tieto vahvistetusta kuolemansyystä voi viipyä vielä tämän jälkeen jopa kuukausia. 
Tiedon viive on näkynyt epidemian aikana niin raporteilla, uutisoinneissa kuin sosiaalisen median keskustelussa. Jatkuvasti päivittyvä tilannekuva tuo esille, miten tieto kehittyy. Tämä voi itsessään heikentää mielikuvaa tiedon luotettavuudesta, sillä tiedon itseään korjaava luonne näyttäytyy poukkoilevana. Esimerkiksi yhtenä päivänä voi näkyä, kuinka koronavirustautiin sairastuneiden tai kuolleiden määrä vähenee, kun tietoa on korjattu tai tarkennettu. Muutokset raportoidussa tiedossa kertovat taustalla olevista toimintaprosesseista - viikonloppuna voi olla vähemmän uusia koronatapauksia, koska kapasiteettia on vähemmän. Tiedon tulkinta edellyttää, että tunnetaan perusteet siitä, miten tieto itsessään syntyy ja miten sitä käsitellään.

Päivittyvän tietopohjan kanssa on kyettävä tekemään päätöksiä tulkinnan, trendien ja ennusteiden valossa. Päätöksentekijä ei voi katsoa vain sitä, mitä mittari kertoo menneisyydestä vaan arvioida sen tulevaa kehitystä ja millä tavalla tieto korjaa itseään. Päätöksenteon hetkellä saatavilla olevan tiedon valossa tehtyjä päätöksiä tulee myös pystyä korjaamaan, kun parantuva tieto antaa siihen syytä.

Jokainen havainto voidaan käsittää väittämänä, johon liittyy mittaustulos ja todennäköisyys siitä, kuinka totuudenmukainen se on. Jokaisessa tietolähteessä ja mittausmenetelmässä on sisäänrakennettu virhe, jonka suuruus voi vaihdella ajan suhteen.

Laboratoriovarmistettu nukleiinihappotesti (PCR) on luotettavin mittari sille, onko henkilö sairastunut koronavirukseen. PCR-testin herkkyys on $95 \%$. Jotta testi on luotettava, näyte on pitänyt kerätä oikein ja oikeaan aikaan suhteessa sairauden kehittymiseen. Testi on luotettavimmillaan ensimmäisellä viikolla oireiden alkamisen jälkeen. Neljän viikon jälkeen positiivisten tulosten määrä vähenee, ja näytteenottokohta vaikuttaa enemmän tuloksiin. Tässä vaiheessa kuitenkin vasta-ainetestit voivat havaita, että henkilö on sairastanut koronan.

Laboratoriovarmistetuista tautitapauksista saadaan vahva signaali tautitapausten määrästä. Osalle ei kehity oireita, osaa taas ei ole syystä tai toisesta testattu. Osalla testi on palautunut negatiivisena, vaikka olisi jo sairastunut. Näin saatu tautitapausten määrä ei siis kata kaikkia sairastuneista. Tilannekuvan kannalta tulisi pystyä näiden havaintojen perusteella ennakoimaan, miten tilanne kehittyy sekä korjata malleja ja niiden parametreja uusien havaintojen avulla.

Ajallisesti tietoa epidemian alkamisesta ja etenemistä voidaan arvioida heikkojen signaalien avulla. Sosiaalisen median keskustelut (7), hakukoneiden tilastot (8) tai vaikka ostokäyttäytyminen voi kertoa siitä, että jonkin sairauden tyypilliset oireet ovat lisääntymässä. Tätä on käytetty muun muassa influenssaepidemioiden seurannassa, jossa tällaisen tiedon avulla voidaan ennakoida epidemian alkua 1-2 viikkoa aikaisemmin. Tällainen tieto ei kuitenkaan pysty kertomaan yhtä suurella varmuudella, onko kyse esimerkiksi nuhakuumesta, influenssasta tai koronavirustaudista.

Suomessa julkaistiin maaliskuussa lääkinnällisenä laitteena koronavirusoirearvio. Tällä verkkotyökalulla kuka tahansa pystyy arvioimaan vastaavatko omat oireet koronavirustautia ja ottamaan yhteyttä terveydenhuoltoon tarvittavia jatkotoimenpiteitä varten. Oirearviotyökalu kertoo tarkemmin siitä joukosta, jotka kokevat, että heillä voi olla koronavirustauti.

Keskustelussa, hakukoneissa ja oirearviossa sekoittavana tekijänä on yleinen keskustelu ja tautiin liittyvä uteliaisuus. Oireiden alkaessa on helppo päätyä omaan tulkintaan siitä, että kyseessä on korona, koska siitä puhutaan. Vaikka oireita ei olisi, niin lisätiedon etsiminen taudista kiinnostuksen vuoksi vahvistaa signaalia, vaikka epidemian kannalta mikään ei ole muuttunut.

Perusterveydenhuollon käyntisyyseurannasta saa yhä tarkempaa tietoa siitä, miksi eri henkilöt ovat hakeutuneet hoitoon. Sairastuneen käyntisyyksi on voitu merkitä esimerkiksi koronavirustauti, epäilty covid-19 tai vahvistettu covid-19. Toisaalta käyntisyynä on voinut myös olla vatsatai selkäkipuja, jotka voivat olla olleet koronavirustaudin aiheuttamia. Oireiden määrää seuraamalla voidaan arvioida taudin yleisyyttä. Samat oireet voivat olla kuitenkin peräisin myös muista sairauksista.

Koronavirustauti on osalla siihen sairastuneista oireeton. Kaikki sairastuneet eivät myöskään käytä terveydenhuollon palveluja syystä tai toisesta. Todellinen sairastuneiden määrä on tämän vuoksi suurempi kuin raportoitujen tautitapausten määrä. Väestö- ja aluetasolla havaittujen tapausten määrää ja todellista tapausten määrä on selvitetty muun muassa vasta-ainetestien ja jätevesitutkimusten avulla. Vasta-ainetestien luo- 
tettavuus kuitenkin riippuu taudin yleisyydestä. Lisäksi testien havaitsemat vasta-aineet muodostuvat muutaman viikon viiveellä suhteessa PCR-testin kykyyn tunnistaa tapaus.

Eri tietolähteitä vertailemalla ja seuraamalla pystytään arvioimaan kunkin lähteen oikeellisuutta ja vahvuutta. Kun eri lähteiden väliset suhteet tunnetaan, heikompia signaaleja voidaan hyödyntää ja ennakoida niiden avulla tilanteen kehittymistä. Oikean ja hyväksyttävän päätöksen tueksi tarvitaan riittävän luotettava ja vahva signaali. Vasta jälkikäteen voidaan arvioida, olisiko heikomman signaalin varassa pitänyt toimia vai ei.

\section{TIEDONKERUU JA SEN LAAJENTAMINEN KATVEALUEILLE}

Koronaepidemian hoito edellytti laaja-alaista kansallisen tietopohjan hyödyntämistä, tietotuotannon nopeuttamista sekä tietotuotannon laajentamista sen katvealueille. Kevään 2020 koronavirustautia ja siihen varautumista kattavat jatkuvat havainnot kerättiin kuudestatoista säännönmukaisesti koottavasta tietolähteestä sosiaali- ja terveydenhuollosta. Lähteistä kahdeksan kehitettiin tilannetta varten. Tämän lisäksi tietoa täydennettiin useista erillislähteistä ja laajan tiedonvaihdon avulla.

Käytettävissä olevat tiedot, tiedonkeruut ja raportit kehittyivät ja laajenivat vähintään viikoittain. Kehittämisvauhdille oli toisaalta tarvetta epidemian vuoksi, mutta samalla tuli kuroa umpeen aiempien vuosien aikana kertynyttä kehittämisvelkaa tietotuotannossa ja vahvistaa osaamista ja resursseja eri pullonkaulojen ja riskien minimoimiseksi.

Tietotuotannon kannalta keskeisessä roolissa on toiminut tartuntatautirekisteri. Rekisteriin kerätään jatkuvasti lääkäreiden ja laboratorioiden toimittamia tartuntatauti-ilmoituksia. Uusi tartuntatauti edellytti muutoksia järjestelmään ja sen ohjeistukseen, mitkä olivat tuotannossa maaliskuussa.

Terveydenhuollon palveluiden käyttöä seurataan hoitoilmoitusrekisterin avulla. Perusterveydenhuollon osalta rekisteri on päivittynyt päivittäin. Erikoissairaanhoidon tiedoissa päivityssykli oli ennen koronaepidemiaa tihentymässä kohti kuukausittaista tiedonkeruuta, mutta epidemian vuoksi suurimmat sairaalat ja sairaanhoitopiirit siirtyivät päivittäiseen tiedon toimittamiseen. Jot- ta tiedot olisivat keskenään vertailukelpoisia ja seurattavia, kansallisia tauti- ja toimenpideluokituksia ja niiden ohjeistusta tarkennettiin ja päivitettiin.

Laki terveyden ja hyvinvoinnin laitoksesta uudistui toukokuussa 2019. Tämä lakimuutos antoi THL:lle aiempaa laajemmat käsittelyoikeudet sosiaali- ja terveydenhuollon tiedoille. Nämä käsittelyoikeudet antoivat THL:lle mahdollisuuden saada ensimmäistä kertaa laajamittaisesti tietoja suoraan Kanta-palveluista. Tiedonsaantioikeudet mahdollistivat myös tehohoitorekisterin tietojen hyödyntämisen kansallisessa tietopohjassa. Sosiaali- ja terveydenhuollon tietojen lisäksi tiedot yhteiskunnan perusrekistereistä kuten väestötietojärjestelmä ovat osa tietotuotantoa.

Henkilörekisteripohjaista tiedonkeruuta täydennettiin organisaatiokohtaisilla resurssikyselyillä perus- ja erikoissairaanhoidon sekä sosiaalihuollon toimijoille. Nämä jatkuvasti päivittyvät kyselyt täydensivät tilannekuvaa muun muassa tiedoilla kuntien ja sairaanhoitopiirien testauskapasiteetista ja hoitopaikoista.

Tieto epidemian etenemisestä ei yksin ollut riittävää yhteiskunnan tarpeisiin. COVID-19epidemian hallinnan keskeisiä kysymyksiä oli toisaalta epidemian rajoitustoimien aiheuttama sosiaalinen, taloudellinen ja muu kuorma yhteiskunnalle. Asiantuntijuuden ja ajantasaisen tiedon varassa pystyttiin tekemään vaikutusarvio väestön palvelutarpeeseen, palvelujärjestelmään ja kansantalouteen (9).

\section{JAETTU TAVOITE POISTAA ESTEET}

Yhdessä koettu poikkeustila antoi eri sektorin ammattilaisille ja heidän edustamilleen organisaatiolle yhteisen selkeän tavoitteen. Toimiala- ja organisaatiorajat tuntuivat jäävän taka-alalle, jotta kaikkiin vaikuttava ongelma saataisiin ratkaistua. Tämä puolestaan nopeutti useita jo osin käynnissä olevia prosesseja tietotuotannon ajantasaisuuden ja automaation kehittämiseksi. Nämä kehitysaskeleet ovat vaatineet merkittäviä panoksia ja joustavuutta julkisen ja yksityisen terveydenhuollon palvelunantajien sekä näiden tietojärjestelmätoimittajien piirissä. Tilanteen kannalta keskeisen tietotuotannon varmistaminen on edellyttänyt myös muun toiminnan jättämistä taka-alalle sekä joustavuutta sopimuskumppanien puolelta. 
Tiedon hyödyntämisessä on ollut tärkeää, että on kyetty luomaan selkeät ja säännölliset kanavat tiedon kulkemiseen. Keskeisessä roolissa on olleet yhteiskunnan ja terveydenhuollon palvelunantajien valmiusorganisaatiot ja suunnitelmat, joiden kansallinen ja alueellinen tilannekuva on ollut jatkuvan arvioinnin ja hyödyntämisen kohteena. Tämä puolestaan pitää huolen, että tiedon laatu kehittyy kiihdytetyllä tahdilla, kun sen mahdolliset virheet ja harhat ovat avoimesti käsittelyssä.

Tiedon tuotannon, käsittelyn ja raportoinnin osalta ratkaisuja, palautetta ja apua on saatu kiitettävästi niin yliopistojen ja korkeakoulujen, yksityisen sektorin, median kuin yksityisten henkilöiden kautta. Useat keväällä luodut tiedon tuotantolinjat, saati raportointikanavat eivät olisi olleet käytössä ilman tällaista yhteiskuntavastuullista panosta.

Toisaalta on huomattava, että yhteistyön ja avun vastaanottaminen kuluttaa itsessään voimavaroja. Ohjelmistoteollisuudessa tämä tunnetaan Brooksin lakina: "Tekijöiden lisääminen viivästymisen korjaamiseen vain viivästyttää lisää" (10). Voidaan arvioida, että epidemia loi tilanteen, jossa kaikki tuotokset olivat kerralla myöhässä. Tarve viestinnälle kasvaa eksponentiaalisesti suhteessa osapuolten määrään. Mikäli ratkaistavaa ongelmaa ei pystytä pilkkomaan pienempiin osiin, yhä suurempi osa ajasta kuluu siihen, että varmistetaan ettei tehdä päällekkäistä työtä ja pysytään tavoitteessa. Lopulta yhteistyö- ja avuntarjousten määrä on epidemian aikana ollut niin suuri, että niiden käsittely, arviointi ja juridisten seurausten käsittely olisi vaatinut suuremmat resurssit kuin oli käytössä. Samalla varmasti monta erittäin arvokasta ja hyödyllistä ratkaisua on jäänyt hyödyntämättä.

\section{LÄHTEET}

1. Leskelä, RL et al (2019), ” Tietojohtaminen ja sen kehittäminen: tietojohtamisen arviointimalli ja suosituksia maakuntavalmistelun pohjalta”, Valtioneuvoston selvitys- ja tutkimustoiminnan julkaisusarja 2019:42, VNK, http://urn.fi/ URN:ISBN:978-952-287-754-3

2. Oderkirk, J. (2017), "Readiness of electronic health record systems to contribute to national health information and research", OECD Health Working Papers, No. 99, OECD Publishing, Paris, https://doi.org/10.1787/9e296bf3-en.

\section{KANSALLINEN TIETOPOHJA ON OSA VARAUTUMISTA ODOTTAMATTOMAAN}

Kansallinen tietopohja muodostaa vakiintunen pohjan tiedolle, jota voidaan käyttää päätöksenteon tueksi. Vakiintuneessa tietopohjassa ei ole kustannusvaikuttavaa varautua kaikkiin mahdollisiin tilanteisiin ja tietotarpeisiin. Sen vuoksi on löydettävä tasapaino jatkuvan tietotuotannon ja muuntautumiskyvyn välillä.

Nopeasti kehittyvässä tilanteessa päätöksiä on kyettävä tekemään epävarmuuden vallitessa. Toimiva ja ajantasainen tietotuotanto antaa mahdollisuuden seurata päätösten vaikutuksia lyhyellä aikajänteellä. Kyky toimia yhdessä ja tuottaa lisää tietoa poikkeavassa tilanteessa antaa myös mahdollisuuksia tietoon perustuvaan päätöksentekoon ja kokeellisiin asetelmiin päätösten vaikutusten arvioinnissa. Laaja-alainen tilanteen arviointi antaa päätöksentekijälle mahdollisuuden painottaa ja arvottaa päätöstensä monimutkaisia vaikutuksia.

Tietotuotanto koronaepidemian tarpeisiin ei olisi onnistunut ilman, että eri toimijat puhalsivat yhteen hiileen. Julkiset ja yksityiset toimijat ja tieteellinen yhteisö toimivat aktiivisesti ja aloitteellisesti. Yhteinen ponnistus vei kohdennetulla alueella suomalaista sosiaali- ja terveydenhuollon tietotuotantoa kerralla nopeammin eteenpäin kuin koskaan aikaisemmin.

\section{Aleksi YrTtiaho \\ tiedonhallintajobtaja, THL}

Pekka Rissanen

tietoylijobtaja, THL

3. Jormanainen, V. (2018). Large-scale implementation and adoption of the Finnish national Kanta services in 2010-2017: a prospective, longitudinal, indicator-based study. Finnish Journal of EHealth and EWelfare, 10(4), 381-395. https://doi.org/10.23996/fjhw.74511

4. Rantanen, H (2018), "Tilanne kuvan tuottaminen, hyödyntäminen ja jakaminen - Kriittinen nykytilan tarkastelu", Aluehallintovirastojen julkaisuja $42 / 2018$ 
5. Hämäläinen, P et al (2019), "Ehdotukset soteohjauksen mittareista ja tietopohjan varmistamisesta", STM:n raportteja ja muistioita 2019:33, STM http://urn.fi/URN:ISBN:978-952-00-4066-6

6. Parhiala, K et al (2020), "Tiedon käyttö palvelujärjestelmän arvioinnissa : THL:n arviointitoiminto ja Tietoikkuna”, Työpaperi 25/2020, THL, http://urn.fi/ URN:ISBN:978-952-343-512-4

7. Aramaki E, et al (2011) "Twitter Catches The Flu: Detecting Influenza Epidemics using Twitter”. Proceedings of the Conference on Empirical Methods in Natural Language Processing, 15681576, ACM.
8. Ginsberg J et al (2009), ”Detecting influenza epidemics using search engine query data." Nature 457, 1012-1014 (2009). https://doi.org/10.1038/ nature 07634

9. Rissanen, P. et al (2020), " COVID-19epidemian vaikutukset väestön palvelutarpeisiin, palvelujärjestelmään ja kansantalouteen : nopea vaikutusarvio", Raportti 8/2020, THL http://urn. fi/URN:ISBN:978-952-343-496-7

10. Brooks, F (1974) "The Mythical Man-Month" Addison-Wesley. 